\title{
FACILITATING SPIRITUAL INTELLIGENCE IN SOUTH AFRICAN SECONDARY SCHOOL LEARNERS
}

\author{
Author: \\ Ferreira, $\mathrm{C}^{1}$ \\ Prof. Schulze, $\mathrm{S}^{1}$

\section{Affiliation:} \\ ${ }^{1}$ Department of Psychology \\ of Education, Unisa
}

Correspondence to:

Ferreira, C

Email:

ferrec@unisa.ac.za

Correspondence to:

Prof. Schulze, $\mathrm{S}$

Email:

schuls@unisa.ac.za

\section{Postal address:}

PO Box 392,

Pretoria,

0003

\section{Dates:}

Published: 01 Des. 2015

How to cite this article: Ferreira, C. \& Prof. Schulze, S., 2015, 'Facilitating spiritual intelligence in South African secondary school learners'. KOERS - Bulletin for Christian Scholarship, 80(2). Available at: http:// dx.doi.org/10.19108/ koers.80.2.2228

\section{Copyright:}

(c) 2015. The Author(s). Published under the Creative Commons Atribution License.
This article was motivated by concern for the challenges - on a spiritual level - that secondary school learners in South Africa face in the context of moral decay. It therefore aims to develop educational strategies that Life Orientation teachers in particular can use to facilitate spiritual intelligence (SQ) in learners, especially when religious and cultural diversity in schools is considered. To this end, a programme to develop SQ was designed based on a literature review, and then implemented within the framework of socio-constructivism. Purposive sampling was employed to select 10 Grade 11 learners in a secondary school in Pretoria. The programme was implemented with the learners in seven contact sessions over a period of three months. To evaluate the programme, a qualitative case study design was employed. Continuous evaluation during implementation was by means of learner reflective activities, informal conversation interviews, focus groups, semistructured interviews, observations and a researcher self-reflective journal. The findings of this exploratory study revealed that certain content and educational strategies can facilitate SQ in secondary school learners.

Key words: Spiritual intelligence, secondary school, educational strategies, socio-constructivism

Hierdie artikel is gemotiveer uit kommer oor die uitdagings van ' $\mathrm{n}$ spirituele aard en binne die konteks van morele verval, waarvoor sekondêreskool-leerders in Suid-Afrika te staan kom. Die doel was dus om onderrigstrategieë te ontwikkel wat veral Lewensoriënteringonderwysers kan gebruik om spirituele intelligensie in leerders te fasiliteer, met in agneming van godsdienstige en kulturele diversiteit. Met dié doel voor oë is 'n program om spirituele intelligensie te ontwikkel uit die literatuur ontwerp en geïmplementeer binne die raamwerk van sosio-konstruktivisme. Doelbewuste steekproefneming is gebruik om tien Graad 11-leerders in 'n sekondêre skool in Pretoria te selekteer. Die program is met die leerders geïmplementeer in sewe kontaksessies oor ' $n$ periode van drie maande. Om die program te evalueer het die studie 'n kwalitatiewe gevallestudie-ontwerp gebruik. Kontinue evaluering is gedurende hierdie tyd gedoen deur middel van aktiwiteite wat leerder-refleksie stimuleer, asook informele onderhoude, fokusgroepe, semi-gestruktureerde onderhoude, observasie en 'n joernaal met navorser-refleksies. Die bevindinge van hierdie eksploratiewe studie toon aan dat sekere inhoude en opvoedkundige stragtegieë spirituele intelligensie van sekondêreskool-leerders kan fasiliteer.

Kernbegrippe: Spirituele intelligensie, sekondêreskool, opvoedkundige strategieë, sosio-konstruktiwisme 


\section{INTRODUCTION}

Who am I? Why am I here? Where do I fit in? What really matters in life? Seeking answers to these existential questions has plagued most of mankind since time immemorial. Research has shown that seeking answers to these questions lies at the core of being human. Gardner (1993:20) refers to these existential questions as "the human proclivity to ponder the most fundamental questions of existence".

SQ is an innate human potential and is concerned with the inner life of mind and spirit. Like any talent, it is expressed in various ways and to various degrees throughout the human population. It is the intelligence that brings forth an awareness of ultimate values and their meaning, the ability to use spiritual resources to solve problems, the capacity to engage in virtuous behaviour and to obtain a deep understanding of existential questions and insights into multiple levels of consciousness (Emmons, 2000a:10; Noble, 2001: 46; Schuller, 2003: 9; Sisk, 2008: 25; Vaughan, 2002:19; Wolman, 2001: 83).

Existential questions such as the above, speak to critical identityrelated issues, social relationships, spirituality and ideology during adolescence (Magaldi-Dopma \& Park-Taylor, 2013:43). Adolescents, irrespective of their religious orientations, are on a quest for purpose and meaning in their lives and therefore seek answers to these questions. If they remain unanswered, their search for meaning may result in anxiety and a sense of emptiness and isolation (Damon, Menon \& Bronk, 2003; Weems, Costa, Dehon \& Berman, 2004).

In South Africa, many of the adolescents who search for meaning in their lives do so while studying in secondary schools that are sites of prejudice, disrespect and racial intolerance (Burton, 2008:2012). In addition, numerous schools are scenes of moral and social degradation that display criminality, vandalism, bullying, academic failure and school dropout (Burton \& Leoschut, 2012; Solomons \& Fataar, 2010:2). Adolescents' personal contexts are also often unstable and add to the moral decay (Dirkx, 2001:79).

In the light of the above, we argue that it has become essential to transform the South African education system and to cultivate character traits in learners that include hope, connectedness, compassion, meaning and tolerance (De Souza, 2006). As these traits are indicators of SQ, the development of SQ in learners would be an appropriate response on the part of schools and Life Orientation (LO) teachers in order to address the above issues. An electronic search using ProQuest Education did not turn up a single South African publication that aimed at encouraging the development of SQ, indicating a huge void in current research. Ultimately, learners with a high SQ have the potential to alter the evolutionary path of humankind (Schuller, 2003:9) because they have a desire to make a difference. However, the multi-cultural and multi-religious character of schools challenges teachers. Christianity is embedded in the ethos of most South African secondary schools, and many of the teachers are confined within their own belief systems ( $\mathrm{Du}$ Preez, 2009:94).
The South African National Curriculum Statement (Department of Basic Education, 2012), which prescribes what needs to be taught in the different subjects in school, supports Gardner's (1999) Multiple Intelligence (MI) theory. Gardner originally identified eight intelligences. We argue that SQ can be distinguished as a ninth intelligence since it meets at least three of the accepted criteria for intelligences (King, 2008; Noble, 2001; Vaughan, 2002; Zohar \& Marshall, 2000). Firstly, evolutionary biology has suggested that the human brain provides an integrative structure for religious beliefs and practices (Emmons, 2000a:13-14; Kirkpatrick, 1999:934-935). The neural organisation in the brain makes it possible to engage in creative, insightful, intuitive thinking which are primarily in the temporal lobe (Ramachandran, Blakeslee \& Sacks, 1998; Persinger, 1996). Siegel (2009:143) also indicates that the middle prefrontal area of the brain can facilitate perception of the inner world and mediate the important SQ capacities of empathy, morality, atonement and insight. Secondly, individuals who are considered to be spiritually exceptional support the notion of SQ. For example, Catholic mystics such as St Theresa of Avila and St John of the Cross may be regarded as evidence that spiritual skills are highly developed in certain individuals (Gardner, 1997:92). Thirdly, in examining the relatedness between different intelligences, it has been found that measures of spiritual transcendence and religious attitudes are statistically independent of measures of general intelligence (Piedmont's, 1999: 998; King and DeCicco, 2009: 68). Viewing SQ as a ninth intelligence has vast implications for LO teachers who are responsible for addressing controversial concepts of values, religion and spirituality in multi-cultural and multi-religious contexts.

To develop SQ in learners, teachers need to consider socioconstructivist theory. This theory takes into account the fact that learners have unique perspectives regarding their belief systems and world-views (Karagiorgi \& Symeou, 2005:17). It requires that learners be actively involved in their learning since the teaching is learner-centred. The collaborative nature of the teaching allows the learners to compare and understand multiple perspectives on issues. Thus it admits epistemic relativity as true, which has the potential to stimulate critical dialogue on religious and spiritual content (Du Preez, 2009). As Christians, the authors also endorse the idea of religious conversations in school that can cultivate tolerance and mutual understanding.

\section{LITERATURE REVIEW}

A clear distinction needs to be made between $S Q$, intellectual intelligence (IQ) and emotional intelligence (EQ) (Zohar \& Marshall, 2000:4-7). According to Bowell (2004:6-10), IQ is rule-bound and employs logical and linear thinking to solve rational problems. EQ allows associative, habit-bound, and pattern-recognising thinking which leads to an awareness of one's own emotions and those of other people and the management of one's own emotions (Goleman, 1995:32). SQ, however, can transport IQ and EQ to higher levels of thinking by activating specific neural organisations of the brain that develop unitive, holistic thinking and rest on integrating whole-brain phenomena (Zohar \& Marshall, 2000:62), thus 
allowing an individual to be creative, intuitive and reflective.

King (2008) theorised that SQ encompasses a distinct set of mental abilities that are associated with spirituality, such as critical existential thinking, personal meaning production, transcendental awareness and conscious state expansion which, when developed, can help adolescents to adapt. As key concepts in this study, these abilities are briefly explained next:

Critical thinking is "the capacity to critically contemplate the nature of existence, reality, the universe, space, time, death, and other existential or metaphysical issues" (King, 2008:57). According to Emmons (2000b:1), this ability resonates with "thoughtful reflection" or what Evans and Wellman (2006:471) refer to as "existential reasoning". The ability to contemplate and analyse issues of an existential nature which characterise the adolescent phase of development implies that adolescents could seek solutions to problems in times of crises.

Personal meaning production is "the ability to construct personal meaning and purpose in all physical and mental experiences, including the capacity to create and master a life purpose" (King, 2008:62). This aligns with Reker's (1997:710) views that personal meaning is "having a purpose in life and a sense of direction" for the attainment of goals and herein we find a distinct mental capacity. The ability to derive meaning from one's environment facilitates adaptiveness in a variety of situations (King, 2008:85-86). Such spiritual meaning can shield an individual against the effects of stress and depression (Mascaro \& Rosen, 2006:183). This will be of value to adolescents as their quest for purpose and meaning is often accompanied by increasing levels of anxiety and a sense of personal emptiness.

Transcendental awareness refers to individuals' ability to identify divine dimensions of themselves, of others, and of the physical world in addition to the capacity to identify relationships to themselves and to the physical world (King, 2008:65). Thus, transcendental awareness refers to surmounting the ordinary constraints of physicality and developing a meaningful awareness of a divine being and of oneself (Emmons, 2000a:10). Such holistic awareness can enable adolescents to consider all facets of a dilemma, thus enabling a more complete perspective on problems, which can lead to effective solutions. Transcendence also promotes a sense of connectedness which plays a significant role in overall wellness, particularly in the lives of adolescents (Piedmont, 2004).

Finally, conscious state expansion is the capacity to enter and exit spiritual states of consciousness at one's own discretion, for example during meditation and prayer (King, 2008:72). Such states involve altered brain activity compared to the waking state, making them more than just heightened awareness (Cahn \& Polich, 2006:191). This ability could prevent various forms of self-destructive behaviour and is thus worth considering as a mechanism for dealing with the moral dilemmas that adolescents are often confronted with. By entering different states of consciousness, new patterns of repeated neural circuit activation strengthen the synaptic connections which lead to synaptic growth in the brain. Any form of meditative practice harnesses neural plasticity to alter synaptic connections in a way that transforms a temporary state into a more lasting trait of the individual (Siegel, 2009:141).

A distinction between the brain and the mind is also paramount for two reasons. Firstly, it provides an understanding of where SQ resides. According to Zohar and Marshall (2000:5) "SQ is the intelligence that rests in the deep part of the self that is connected to wisdom from beyond the conscious mind". This implies that all humankind is connected to this intelligence, irrespective of race, colour or creed. Secondly, it alludes to a conscious and a subconscious mind and how meditative practices have the potential to quieten one's thoughts and tap into the deeper regions of the mind which ultimately changes the brain (Siegel, 2009:141). Hence, the potential to reprogramme the subconscious mind is evident (Hamilton, 2010; Horgan, 1999; Lipton, 2010; Murphy, 2011; Williams, 2002).

The above has significant implications for researchers who aim to facilitate SQ in adolescents. King (2008) also identified possible content and activities to promote unitive and higherorder thinking. With this in mind, we selected the following topics for a programme to develop SQ in adolescents: exploring the nature and core traits of SQ; developing self-awareness; becoming aware of the power of thought; opening up to different perspectives of an issue; delving into connectedness; exploring multi-levels of consciousness; and examining the power of the subconscious mind. We also selected the following techniques in the programme presentation: discussions and debate; studying the life of a pathfinder; reflective activities; storytelling; PowerPoint presentations with thought-provoking quotes, scientific facts and visual illustrations; meditation and breathing exercises; guided visualisation with music and whole-brain integration exercises. The programme was subsequently implemented and evaluated qualitatively.

\section{RESEARCH METHOD}

Since the study was exploratory, a qualitative, case study design was deemed appropriate. Purposive sampling was used to select a sample of 10 Grade 11 learners, who reflected the demographics of South Africa's population, from a dualmedium secondary school in Pretoria. The programme to develop the learners' SQ was implemented with the sample by one of the authors of this article. Seven sessions were held after school hours over a period of three months and lasted two to three hours each.

Data was collected throughout programme implementation and thereafter. The learners kept journals with reflective activities. These were complemented by means of informal interviews during each session that were recorded as field notes, together with observations, in a self-reflective journal. At the end of the programme, a focus group and semi-structured interviews were conducted and recorded. Among other things, the focus was on what worked well, what did not work well, and what could be done to improve the programme. More clarity was also obtained from the data that were obtained during the sessions. 
Ethical clearance required informed consent from all relevant parties (including the permission of parents or guardians), assurances of confidentiality and anonymity, avoidance of deception, and ensuring researcher competence (McMillan \& Schumacher, 2014:129-131). Strategies used to warrant trustworthiness included a prolonged period of three months for data collection, the use of multi-method strategies, mechanically recorded data, verbatim accounts and low inference descriptors, multiple researchers, and conducting the research in the natural school environment.

The next section illustrates the findings. For ease of reference, a code is assigned to each participant, for example $\mathrm{A} / \mathrm{M} / 5$ implies an African male and participant number five, while W/F/1 refers to white, female participant number one.

\section{FINDINGS AND DISCUSSION}

The most important findings are presented in this section. Firstly, the findings illustrate the extent to which selected content facilitated SQ in learners (including how they were presented), and secondly, which techniques were particularly useful.

\section{EXPLORING THE NATURE OF SQ}

The content concerning the nature of SQ was designed to elicit debate around spirituality and religion. The findings revealed that the participants were initially cautious and hesitant to enter an open debate on issues of religion and spirituality, mainly out of fear of exposing the exclusive nature of their Christian faith. Their responses revealed that they were still confined by personal prejudices and ideologies. For example: “This is a very sensitive issue and I don't like to discuss it because I'm scared I'll get confused. I'm Catholic and we don't question our belief" (A/F/1). One can deduce from her response that she had made deep emotional investments in her faith. Fowler (1981:153) labels this view as synthetic-conventional and one that allows little room for critical reflection or openness to other belief systems. Another participant ( $\mathrm{C} / \mathrm{F} / 3)$ stated: "We never talk about spiritual stuff at school." This statement supports our view that, although the new curriculum aims to develop religious literacy (DoE, 2012:7-8), closer analysis reveals that both this and the spiritual dimension are lacking since the learners are generally not exposed to critical dialogue on religious and other belief systems. This is not limited to South Africa, but seems to be a global problem (Lleleji, 2010).

However, the findings also revealed that the participants' understanding of SQ increased with time as a result of the many in-depth discussions and reflective activities around a variety of topics that were included in the programme. As the programme progressed, they became more open to and tolerant of other views, and willing to share their own belief systems. For example:

I am a Christian, although I hardly ever go to church but I believe we all believe in the same God or a "Higher Being" (C/F/3).

Yes, I am also a Christian, but after this SQ class, I feel I can't judge other religions because I don't know enough about them. I suppose I'm more open to learn about them $(\mathrm{A} / \mathrm{M} / 5)$.

Some of these views could be regarded as New Age spirituality. For example:

I just see everybody as one. Actually, if people just not see the human body and just see the soul the end will look the same. It's just a light or a beam of light. We are just like these little beams of light. There's no difference between us (F/W/4).

Mason, Singleton and Webber (2007:174) state that a large proportion of young people move between alternatives, especially during their adolescence, and appear to be drawn towards New Age spiritualties.

One of the participants also expressed his interest in the African traditional belief systems, although he had reservations as to whether he could be treading on sensitive terrain. He stated:

I am interested to hear about what they believe in the black culture, like the other day a girl in our class wore beads around her neck. I don't know enough and then I don't feel its right to ask about it. Nobody asks these questions (C/W/8).

This statement is significant given the fact that the black learners in the school population were in the majority. However, the South African curriculum is modelled on a Western perspective and therefore African spirituality is generally not considered, as has also been noted by others (Breidlid, 2009:146; Ntuli, 2002:65).

The above findings reveal that the learners were able to engage in the critical existential thinking that unlocked the mental abilities of SQ. Certain core traits of SQ became apparent during the course of the sessions, in particular a capacity to reframe a situation or an issue, which required adolescents to stand back from a situation and look for the "bigger picture". Such holistic awareness is regarded as a key component of SQ (Zohar \& Marshal, 2000; 2004), and suggests transcendental awareness (King, 2008). This further aligns with Zohar and Marshall's (2004) view of spontaneity as openness to life's possibilities and an existential readiness to develop purpose and meaning in life. It can further be argued that this capacity could bring about a sense of freedom and liberation, which is regarded as a peak experience of SQ (Sisk, 2008).

However, it was during the focus group at the end of the programme implementation that it became evident that the participants were able to enter into critical dialogue about religious content and its relation to $S Q$, thus allowing for epistemic relativity within the framework of socioconstructivism. This implies that a socio-constructivist approach has the potential to stimulate critical dialogue about religious content and enable learners to be more open to the truths of others, without negating their own belief systems (Du Preez, 2009). The ability to reason on deeper existential levels seemed to be a consequence of the reflective activities and thought-provoking content around the nature of SQ as well as the informal interviews that were conducted during each 
session.

\section{Core traits of SQ: studying the life of a pathfinder}

The findings showed that studying the life of a pathfinder such as President Nelson Mandela has vast potential to develop SQ in adolescents. For example, the following participant revealed his ability to overcome tragedies and setbacks.

Mam, I actually come from an orphanage and I've been in foster homes. But I'm glad today, because when we discussed [President] Nelson Mandela's life, how he had a lot of suffering but used it for a higher cause, I know what it feels like ... today I'm glad, because I have learned more about life than anyone here. And I'm not scared to say what I believe in $(\mathrm{C} / \mathrm{M} / 8)$.

A capacity to transcend pain and suffering normally goes handin-hand with steadfastness that can develop other capacities such as being independently-minded and self-critical (Zohar \& Marshall, 2000), which are mental components that portray $\mathrm{SQ}$.

\section{Self-awareness}

Two reflective activities were developed for seeking answers to questions such as: "Who am I?" and "What is my purpose in life?" The activities put the adolescents in touch with the deepest parts of their being, thus recognising their strengths and weaknesses. This, in turn, enhanced the participants' abilities to continuously recreate themselves and so endow life with personal significance. This is well-illustrated in following excerpt:

These questions got me thinking like, why am I here ... I suppose there must be a purpose. I never thought about that. Like my passion for cooking can be my purpose. It's just how I use it. Like the story you told me about Babette's feast ... how she brought the whole community together through her cooking. I'd like to do that too (F/W/4).

Thus, conceptually, reflective activities aid the development of the mental abilities of SQ as posited by King (2008). In addition, activities that are deliberately designed to develop self-awareness can foster a clear sense of purpose and vocation in adolescents and thus aid personal meaning production.

\section{Storytelling: the parable of the prodigal son}

The findings revealed how SQ activities, such as parables, can be used to generate deeper insights in adolescents while simultaneously providing opportunities to present alternative views of certain issues or, as Zohar and Marshall (2000; 2004) stated, a capacity to reframe situations, thus placing them in a larger context of meaning. These capacities further denote mental abilities such as holistic thinking, which are reflective and broad-minded. For example, during the informal interviews all the participants were able to relay the conventional version of the parable: how the father forgave and welcomed the rebellious son back, irrespective of his transgressions. However, when all the possible character weaknesses of the elder son were pointed out, it opened avenues for discussion that ranged from awe and wonder to deeper insights of his character weaknesses. For example:

I only know about the younger son because he was a rebel, but not about the older son. He had pride and he was angry with his father and jealous of his younger brother. It's the first time I thought about it that way (C/W/9).

It can therefore be argued that storytelling is a powerful tool to develop a range of SQ capacities. The main objective of using this particular parable was to offer an opportunity to introduce multiple perspectives of an issue. The power of stories for understanding oneself and others has also been pointed out by Lleleji (2010).

\section{The power of thought: the "think-feel-speak-act" model}

Discussions around the power of thought revealed that the adolescents had a heightened sense of awareness of the effects of positive thoughts. This is an SQ trait that typifies a transcendental awareness. Examples are:

I am more aware of my thoughts than before I came to this course. I never knew how many thoughts run through my head all the time. It's crazy! But when I focus on my breathing it does help to quiet my mind $(\mathrm{C} / \mathrm{F} / \mathrm{1})$.

Our thoughts are connected and that's why we can affect each other, just like when you throw a stone in the water ... it makes waves. So your thought will flow out and affect other people but those waves will flow back to you. So you must always think positive thoughts if you want a positive life $(\mathrm{C} / \mathrm{M} / 10)$.

Thus, from a conceptual perspective, content surrounding the power of thought is fundamental to understand the brain-mind phenomenon and facilitate SQ. The experiential activities that were used in this instance included meditation and visualisation.

\section{Connectedness}

To develop connectedness in learners, PowerPoint presentations contained thought-provoking quotes (e.g. "If you believe you can, if you believe you can't .... you're right!" - by Henry Ford); scientific facts (e.g. that humans are not victims of their genes); visual illustrations (e.g. of the tip of the iceberg that represents the conscious mind, in contrast to $90 \%$ of the mind which is sub-conscious); and discussions on 12 spiritual laws (e.g. "as above so below, so below as above", implying that whatever individuals think, controls what they say, feel and do, and vice versa). The findings revealed that, in spite of the fact that there was a difference between the degree and the depth of understanding of the idea of connectedness, adolescents offered some profound insights that included:

I realised one thing ... that all these spiritual laws are connected. I look at myself and the world differently, and for me the best part is that it opened my imagination again. I want to write 
scripts and a book one day and finish the stories I wrote when I was young $(\mathrm{C} / \mathrm{F} / 3)$.

One can infer that a conscious state of expansion was experienced that encompassed self-awareness, as well as universal and spiritual awareness.

\section{Exploring multi-levels of consciousness: the brain-mind phenomena}

Content that focussed on the neuroplasticity of the brain or on the origin of thoughts, presented by means of PowerPoint slides, facilitated thought-provoking insights into the brainmind phenomenon which facilitated the development of SQ. For example, during an informal interview, a white male participant showed a capacity to recognise that the brain is tangible ("a physical organ") and the mind is more elusive and intangible ("you can't see it"). This type of understanding has also been found by others (Hamilton, 2010; Williams, 2002). Another participant said:

For me my mind is what I think, what's around me, what I have experienced, what I make of it. I think it's something I have constructed with my thoughts, like I control my own mind. Whatever's in my mind is what eventually changes my brain (F/B/1).

This response not only demonstrates a deep understanding of the capacities of the mind, but also alludes to the neuroplasticity of the brain.

The findings further indicated that the participants gained insight into the functions of the conscious and subconscious mind. For example: "The conscious mind has only a small perspective, but the subconscious mind contains so much more hidden talents and power behind it"(A/M/6). Such insights were possible for the adolescents since they were capable of abstract thought.

\section{Meditation and breathing exercises}

Meditation is inwardly focussed. It is defined as an unceasing flow of one thought, e.g. about God, while completely shutting out worldly thoughts (Meditation: definition and benefits n.d.). Daily meditation is reported to facilitate peace of mind and inner joy, and to bring individuals closer to their own selves. Meditation was therefore a core activity that was implemented to develop SQ. The adaptive functioning of the various meditation activities is well-illustrated in the following responses:

Meditation makes me feel calm (A/F/1).

It feels like I become more peaceful and [it] refreshes your mind $(\mathrm{A} / \mathrm{M} / 5)$.

For me it is like most of the time I walk always around with this noise in my head and it made my thoughts quieter $(\mathrm{A} / \mathrm{F} / 2)$.

For me it's therapeutic and helps me to concentrate better

\section{(A/M/8).}

The meditation exercises conferred a sense of peace and calm, controlled the influx of debilitating thoughts, improved concentration, was therapeutic, and induced a heightened sense of awareness and other peak experiences such as awe and wonderment in the participants, as also found by others (D'Aquili \& Newberg, 2000). Breathing during the meditation exercises helped the participants to experience a conscious state expansion with remarks such as: "Everything looks brighter and as if it's closer" (A/F/2). Meditation has adaptive capacities and can alter brain activity (Lutz, Greischer, Rawlings, Ricard \& Davidson, 2004; O'Nuallain 2009). It facilitates a brainwave pattern that promotes unitive thinking and thus the development of SQ.

\section{Guided visualisation with oceanic music}

Guided visualisation with oceanic music was a technique that facilitated SQ because it developed adaptive functioning. Visualisation provided a vehicle to help the participants to relax in an open, non-judgemental atmosphere. In addition, it helped the adolescents to set goals, focus on areas of concern in their lives and visualise positive outcomes. It thus aided personal meaning production. An example is:

I think the visualisation helped me to focus on my goals. I know what I want to achieve and when I had to say it loudly in my mind, I felt more confident. I often listen to it before I go to sleep (C/M/9).

Thus, visualisation can be very effective in developing SQ, particularly in the adolescent stage of development where openness and goal-setting become vital. Visualisation can also be implemented with relative ease. The learners can simply find a comfortable position in their seats to do the exercise.

\section{Whole-brain integration exercise}

The goal of a whole-brain integration exercise was to increase "cross-talk" between the two brain hemispheres, thereby achieving a more whole-brained state. This state facilitates an experience of multi-levels of consciousness. It is ideal for changing subconscious beliefs that are inhibiting and limiting (Williams, 2002:119), thereby developing an acute self-awareness in adolescence. In addition, it develops a sound understanding of why whole-brain integration is important for enhancing "unitive" and holistic thinking and, thus, the development of SQ.

For whole-brain integration, the participants had to learn the correct posture which entailed a series of four movements that ended with them clasping their palms together, placing them in their laps and relaxing. Each participant then repeated in their mind any "I can" message that they had specifically chosen to re-programme negative beliefs that they had. Any sensory experience that they would have while doing the affirmations would indicate that the subconscious mind might have internalised the new belief. One participant commented on his sensory experiences while doing the exercise as follows: 
It was amazing. I kept saying the message what I wanted my subconscious mind to believe, and the voice from my subconscious mind said: "It's not true". It carried on like that. But I kept saying those words and after about five minutes, I felt less tight here [pointing to his solar plexus], and a warm feeling came over me $(\mathrm{C} / \mathrm{M} / 8)$.

There are alternative ways to develop the whole brain in classroom practice and teachers can select a method with which they feel comfortable, such as meditation.

\section{CONCLUSION}

This article was motivated out of concern for the challenges that secondary school learners in South Africa face on a spiritual level as they function in contexts of moral decay, illustrated by prejudice, disrespect and intolerance. Therefore, we argue for enhancing the SQ of the learners, particularly in the subject Life Orientation. This could challenge teachers who are uncertain how to address spiritual and religious issues in multi-cultural and multi-religious settings. This study therefore aimed to develop, implement and evaluate a programme to develop SQ in learners.

Because of its exploratory nature, the study was limited to one school only. However, the findings are significant in that they reveal that suitable and relevant content, presented by means of socio-constructivist teaching strategies, have the capacity to develop SQ in learners. These strategies include discussions and debate; reflective activities; meditation and breathing exercises; guided visualisation with music and whole-brain integration exercises, using content that is relevant for and interesting to the South African adolescents. The learners who participated in this study demonstrated their SQ through their ability for critical existential thinking, personal meaning production, transcendental awareness and conscious state expansion. However, for these traits to be enforced, programmes need to be on-going in the curricula of secondary schools.

The National Curriculum Statement supports Gardner's MI theory and SQ can be positioned as a separate intelligence in the MI array. This provides the leverage for its inclusion in teacher training. Teachers need training to sensitise them to the transformative power of SQ and its function in dealing with the moral, religious and spiritual dilemmas encountered in educational contexts. They also need training in how to develop their own SQs and those of their learners. High SQ forms the human soul and enables individuals to facilitate change in society. This article is a first step in that direction and makes a significant contribution to new knowledge in the field.

\section{REFERENCES}

Bowell, R.A., 2004, The seven steps of spiritual intelligence, Brealey, London.

Breidlid, A., 2009, 'Culture, indigenous knowledge systems and sustainable development: A critical view of education in an African context', International Journal of Educational Development, 29(2), 140-149.

Burton, P., 2008, Merchants, skollies and stones: Experiences of school violence in South Africa. Centre for Justice and Crime Prevention, Cape Town.

Burton, P. \& Leoschut, L., 2012, School violence in South Africa: Results of the 2012 National School Violence Study. Centre for Justice and Crime Prevention, Cape Town.

Cahn, B.R. \& Polich, J., 2006, 'Meditation states and traits: EEG, ERP, and neuroimaging studies', Psychological Bulletin, 132, 180-211.

Damon, W., Menon, J. \& Bronk, K.C., 2003, 'The development of purpose during adolescence', Applied Developmental Science, 7(3), 119-128.

D’Aquili, E.G. \& Newberg, A.B., 2000, 'The neuropsychology of aesthetic, spiritual, and mystical states', Zygon, 35, 39-51.

Department of Basic Education., 2012, Questions \& Answer booklet for the advocacy of the implementation of the national curriculum statement (NCS) Grades R -12. Pretoria, Government Printer. http://www.education.gov.za/ Date of access: 30 December 2013.

De Souza, M., 2006, 'Educating for hope, compassion and meaning in a divisive and intolerant world', International Journal of Children's Spirituality, 11(1), 165-175.

Dirkx, J.M., 2001, 'Nurturing soul in adult learning', New Directions for Adult and Continuing Education, 74, 79-85.

Du Preez, P., 2009, 'Thinking about knowledge amidst religious diversity: Epistemic relativity and its impact on religion in education', Alternation Special Edition 3, 91-111.

Emmons, R.A., 2000a, 'Is spirituality an intelligence? Motivation, cognition and the psychology of ultimate concern', International Journal for the Psychology of Religion, 10(1), 3-26.

Emmons, R.A., 2000b, Spirituality and intelligence: Problems and prospects. http://www.ehostvgv18.epnet.com/ Date of access: 2 Feb. 2011.

Evans, E.M. \& Wellman, H.M., 2006, 'A case of stunted development? Existential reasoning is contingent on a developing theory of mind', Behavioral and Brain Sciences, 29, 471-472.

Fowler, J.W., 1981, Stages of faith: The psychology of human development and the quest for meaning. Harper Collins, New York.

Gardner, H., 1993, Frames of mind: The theory of multiple intelligence, Basic Books, New York.

Gardner, H., 1997, Extraordinary minds, Basic Books, New York.

Gardner, H., 1999, Intelligence reframed: Multiple intelligence for the 21st century, Basic Books, New York.

Goleman, D., 1995, Emotional intelligence, Bantam Books, New York.

Hamilton, D.R., 2010, How your mind can heal your body, Hay House, Witkoppen.

Horgan, J. 1999, The undiscovered mind, The Free Press, New York.

Karagiorgi, Y. \& Symeou, L., 2005, 'Translating constructivism into instructional design: potential and limitations', Educational Technology \& Society, 8(1), 17-27. 
King, D.B., 2008, Rethinking claims of spiritual intelligence: A definition, model, and measure, Trent University, Peterborough (Master's dissertation).

King, B. \& DeCicco, T.L., 2009, 'A viable model and self-report measure of spiritual intelligence', The International Journal of Transpersonal Studies, 28, 68-85.

Kirkpatrick, L.A., 1999, 'Toward an evolutionary psychology of religion and personality', Journal of Personality, 67(6), 921-952.

Lipton, B.L., 2010, Biology of belief: Unleashing the power of consciousness, miracle and matter, Hay House, Witkoppen.

Lleleji, R.H., 2010, 'Education for justice in the world: A review of 'Growing a soul for social change', Multicultural Reviews, 1-3.

Lutz, A., Greischer, L.L., Rawlings, N.B., Ricard, M. \& Davidson, R.J., 2004, 'Longterm meditators self-induce high amplitude gamma synchrony during mental practice', Proceedings of the National Academy of Science, 101, 16369-16373.

Mascaro, N. \& Rosen, D.H., 2006, 'The role of existential meaning as a buffer against stress', Journal of Humanistic Psychology, 46, 168-190.

Mason, M., Singleton, A. \& Webber, R., 2007, The spirit of generation Y: Young people's spirituality in a changing Australia. John Garrett, Melbourne.

Magaldi-Dopma, D. \& Park-Taylor, J., 2013, 'Practical suggestions for psychologists working with adolescents' religious and spiritual identity', Spirituality in Clinical Practice, 1, 40-52.

McMillan, J.H. \& Schumacher, S., 2014, Research in education: Evidence-based inquiry, 7 th ed. Pearson, Boston.

Meditation: definition and benefits. n.d., http://yoga108.org/pages/ show/108-meditation-definition-and-benefits Date of access: 20 January 2015.

Murphy, J., 2011, The power of your subconscious mind, Martino, Eastford.

Noble, K.D., 2001, Riding the windhorse: Spiritual intelligence and the growth of the self, Hampton Press, New Jersey.

Ntuli, P.P., 2002, 'Indigenous knowledge systems the African renaissance' (in C.A. Hoppers, C.A., ed. Indigenous knowledge and the integration of knowledge systems. Towards a philosophy of articulation. New Africa Books, Cape Town. p 53-66.)

O’Nuallain, S., 2009, 'Zero power and selflessness: What meditation and conscious perception have in common', Journal of Cognitive Sciences, 4(2), 46-64.

Persinger, M.A., 1996, 'Religious and mystical experiences as artifacts of temporal lobe function: A general hypothesis', Perceptual and Motor Skills, 57, 1255-1262.

Piedmont, R.L., 1999, 'Does spirituality represent the sixth factor of personality? Spiritual transcendence and the five-factor model', Journal of Personality, 67(2), 985-1014.

Piedmont, R.L., 2004, 'Spiritual transcendence as a predictor of psychosocial outcome from an outpatient substance abuse program', Psychology of Addictive Behaviors, 18, 213-222.

Ramachandran, V.S., Blakeslee, S. \& Sacks, O., 1998, Phantoms in the brain: Probing the mysteries of the human mind. William Morrow, New York.

Reker, G.T., 1997, 'Personal meaning, optimism, and choice: Existential predictors of depression in community and institutional elderly', The Gerontologist, 37, 709-716.

Schuller, P.A., 2003, Spiritual intelligence. Author House, Indiana.

Siegel, D.J., 2009, 'Mindful awareness, mindsight, and neural integration', The Humanistic Psychologist, 37(2), 137-158.
Sisk, D., 2008, 'Engaging the spiritually intelligence of gifted students to build global awareness in the classroom', Roeper Review, 30(1), 24-30.

Solomons, I.D. \& Fataar, A., 2010, 'A conceptual exploration of values education in the context of schooling in South Africa', South African Journal of Education, $31,224-232$.

Vaughan, F., 2002, 'What is spiritual intelligence?, Journal of Humanistic Psychology, 42, 16-33.

Weems, C.F., Costa, N.M., Dehon, C. \& Berman, S.L., 2004, 'Paul Tillich's theory of existential anxiety: A preliminary conceptual and empirical examination', Anxiety, Stress, and Coping, 17(4), 383-39.

Williams, R.M., 2002, The missing (piece) peace in your life, Hay House, Witkoppen.

Wolman, R.N., 2001, Thinking with your soul: Spiritual intelligence and why it matters, Harmony Books, New York.

Zohar, D. \& Marshall, I., 2000, Spiritual intelligence: The ultimate intelligence, Bloomsbury, London.

Zohar, D. \& Marshall, I., 2004, Spiritual capital: Wealth we can live by, Berret-Koehler, San Francisco. 